\title{
Microstructure and mechanical characteristics of hot forged lateritic steels
}

\author{
Satrio Herbirowo ${ }^{1, *}$, Luqmanul Hakim ${ }^{2}$ and Bintang Adjiantoro ${ }^{1}$ \\ ${ }^{1}$ Research Center for Metallurgy and Materials - Indonesian Institute of Sciences, PUSPIPTEK, 15314 \\ Banten, Indonesia \\ ${ }^{2}$ Department of Mechanical Engineering, Faculty of Engineering, Universitas Negeri Semarang, 50229 \\ Semarang, Indonesia
}

\begin{abstract}
The current development of steel industry has constraints on the availability of raw materials, so we have developed local raw materials that are lateritic steels as a high potential for alternative manufacturing of steel. This research was conducted to understand the characteristics of lateritic steel through hot forging process by the mechanical and microstructure behaviour. The research methodology was chained by variety of preheating temperature of $800 ; 1000 ; 1200{ }^{\circ} \mathrm{C}$ and forging force from 0 until 1000 kilonewton. In case of hot forging values was obtained the impact and hardness properties also microstructure that compared with as-cast steels. The results of impact strength increased by $81.83 \%$ at the temperature of $1200{ }^{\circ} \mathrm{C}$ and the hardness increased by $4.99 \%$ at $1000{ }^{\circ} \mathrm{C}$, for the microstructure analysis was produced the ferrite and pearlite phases with the fine grains. The chemical composition of steel is classified in low carbon steel included in lateritic steel it contains low alloy $1.78 \mathrm{Ni}$ and $0.553 \mathrm{Cr} \%$ wt.
\end{abstract}

\section{Introduction}

In the development of national independence that is the need of steel raw materials, it needs an alternative resource of steel making that is from lateritic nickel ore. The lateritic steel is developed from converting process from Nickel Pig Iron (NPI) 1-2\% nickel content and carbon content above $2 \%$ using oxygen gas blowing to decreased the carbon content in the steel with low nickel content of $0-3,0 \%$ and $\mathrm{Cr}$ by $0-2.5 \%[1]$. In addition to $\mathrm{Fe}$ and $\mathrm{Ni}$ content, laterite steels also contain other elements of $\mathrm{Cr}$ and $\mathrm{Mn}$ in which the two elements will affect the weldability of steel, surface hardness, and corrosion resistance[2].

Previous research about lateritic steel was conducted that the excessive hot forging process on AISI 4340 steel can lead to initiation of cracks due to the reduction of size too large and the inadequate properties and ductility[3]. The cooling rate after the forging process strongly affects to formation of microstructure, fraction volume phase transformation that needs to be controlled[4]. Optimum size reduction significantly affect

\footnotetext{
*orresponding author: satrio.herbirowo@gmail.com
} 
microstructure and SEM observation, to found ductile fracture with a fine grain and good toughness for armour steel application[5].

In this research will be investigated the impact value, hardness value, and characteristics microstructure between phase and grain growth through hot forging method by a recrystallization phenomenon.

\section{Materials and Method}

The laterite casting steel was prepared casting and converting process with material balance simulation. The samples were initial characterization using Optical Emission Spectroscopy Testing to obtain the result of chemical composition. The lateritic cast steel was simulated size reduction by hot forging at highest temperature of $1200{ }^{\circ} \mathrm{C}$ and force load of $1000 \mathrm{kN}$ to determine the maximum reduction in the material.

Furthermore, the laterite steel was actualized by preparation of heated samples in the muffle furnace reached temperature of $800 ; 1000 ; 1200{ }^{\circ} \mathrm{C}$ using thermocouple to ensure calibration of the temperature. Then forging on a variation of forging load of $500 ; 750$; $1000 \mathrm{kN}$ simultaneously. Hot forging steel laterite steel material is cut and machined for the Charpy impact testing process (Figure 1) refers to ASTM E23 standard[6], Hardness Vickers method, and Optical Metallography. Data test results will be processed and analysed by supported the software to get the conclusion

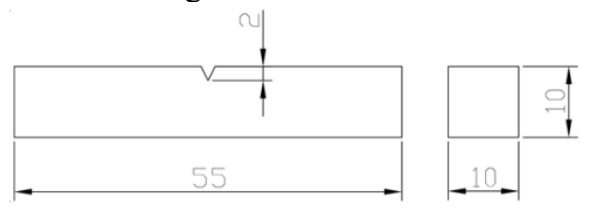

Fig. 1. Impact specimen ASTM E23 standard[6].

\section{Results and Discussion}

\subsection{Chemical Composition}

Below is a chemical composition of the lateritic steel used in the study, are shown in Table 1. These steels are also classified medium carbon steel because it contains Ni element at 1.7833 (\% weight) and $\mathrm{Cr} 0.553$ (\% weight).

Table 1. Chemical composition of lateritic steel using spark OES certified by ARL 3460

\begin{tabular}{|c|c|c|}
\hline No & Element & \%wt \\
\hline 1 & $\mathrm{Fe}$ & 96.347 \\
\hline 2 & $\mathrm{Ni}$ & 1.7833 \\
\hline 3 & $\mathrm{Cr}$ & 0.553 \\
\hline 4 & $\mathrm{Mo}$ & 0.429 \\
\hline 5 & $\mathrm{C}$ & 0.270 \\
\hline 6 & $\mathrm{Si}$ & 0.209 \\
\hline 7 & $\mathrm{Al}$ & 0.184 \\
\hline 8 & $\mathrm{Mn}$ & 0.085 \\
\hline
\end{tabular}




\subsection{Mechanical Properties}

Based on Figure 2 it can be seen an increase on impact strength along with an increase each variation loads in hot forging process lateritic steel.

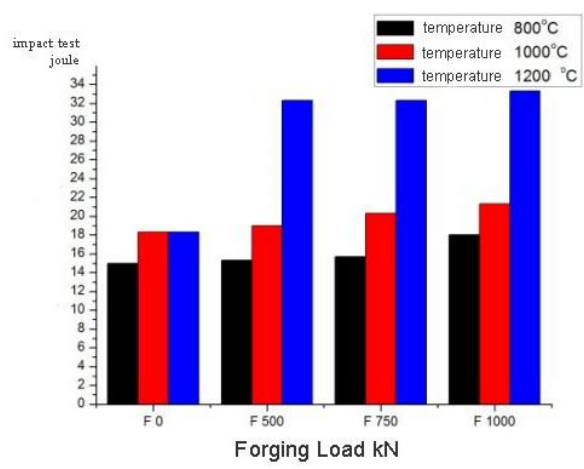

Fig. 2. Relevance of Impact Test and Variety of Forging Loads

From the fracture images of the specimen that the failure types were divided into two criteria fibrous and granular, when compared between the fracture of the specimen without forging (un-deform) and with a load forged of $1000 \mathrm{kN}$ it can be observed that the granular fracture occurring in the specimen was decreasing caused the specimen to become more ductile, due to intergranular fractures are brittle. The hardness test is shown in Figure 3 to the variation of forging load and heating temperature. The highest hardness values were generated on the variation of the forging loads $1000 \mathrm{kN}$ reach $238.9 \mathrm{HV}$, this result increased by $3.37 \%$ compared the un-deformation forging specimen. The highest the temperature were caused weak bonds of the atoms and simplify the plastic sliding process that causes deformation. The size reduction after the hot forging process produced were 0 ; $9.83 ; 12.56$; and $18.25 \%$, as the reduction rate in the hot forging process affects the hardness of the specimen. Reduction causes the specimen to become more flattened due to deformation, the formation of this metal specimen can inhibit the dislocations movement to increased hardness value[3,7].

Physical metallurgy described that multiply the grain boundaries as well as smooth the grain size, which can block the movement of dislocations in material[3]. When viewed from lateritic alloys there is nickel, chromium, molybdenum which has the properties of increasing the ability to increase the hardness[5].

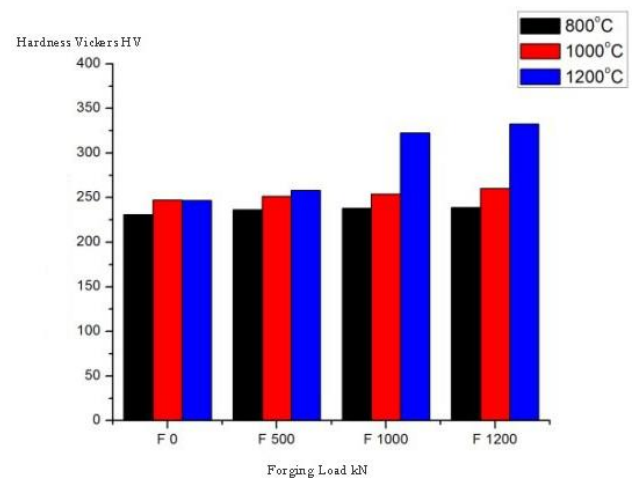

Fig. 3. Relevance of Hardness Test and Variety of Forging Loads 


\subsection{Morphology and Microstructure}

The observation results of microstructure were obtained ferrite and perlite phase. The microstructure of air-cooled specimens comprises ferrite and pearlite matrix on laterite steel resulting from hot forging processes.

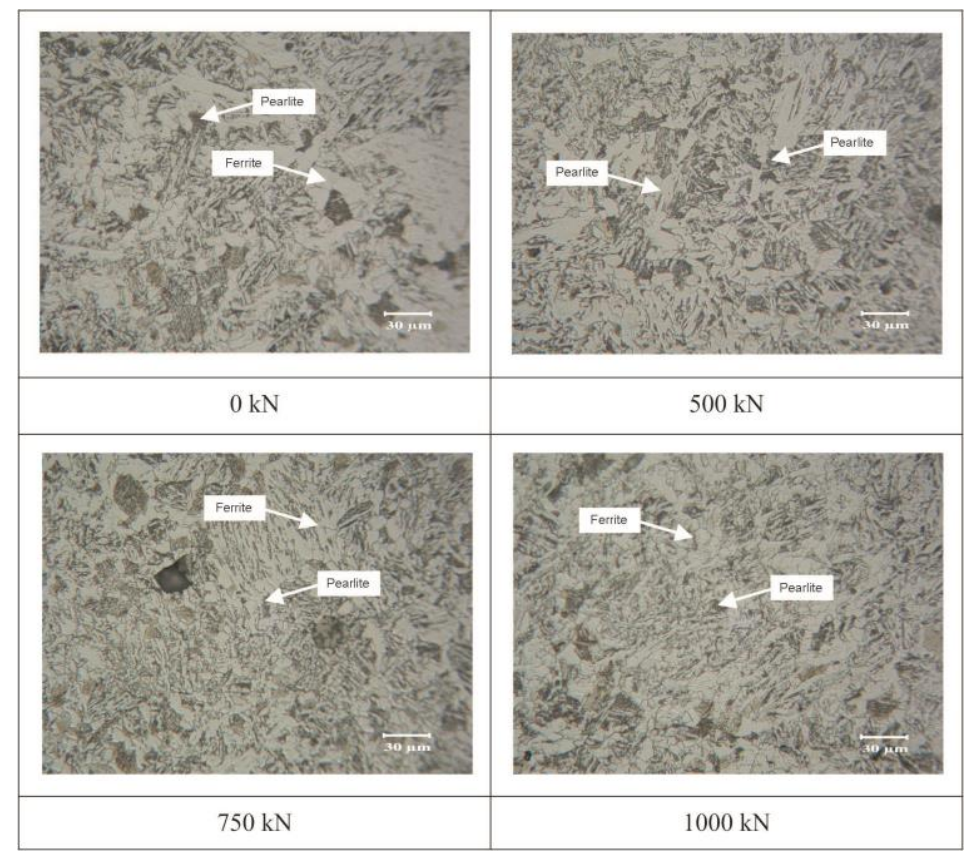

Fig. 4. The state of the microstructure under $800^{\circ} \mathrm{C}$ different forging load conditions.

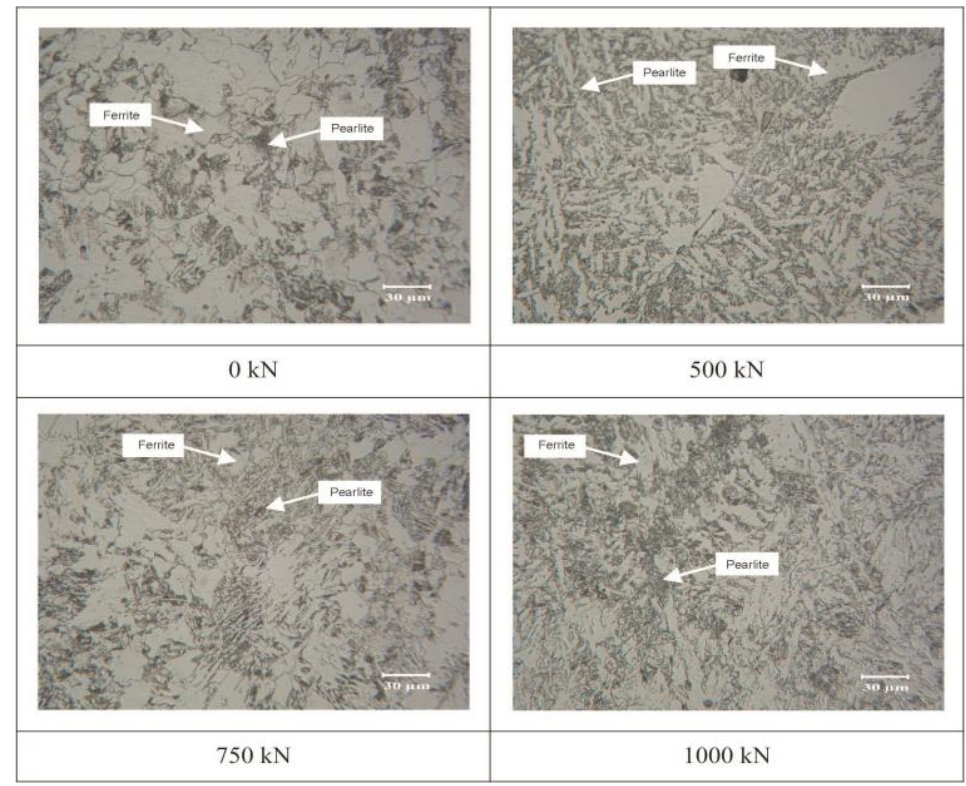

Fig. 5. The state of the microstructure under $1000^{\circ} \mathrm{C}$ different forging load conditions. 


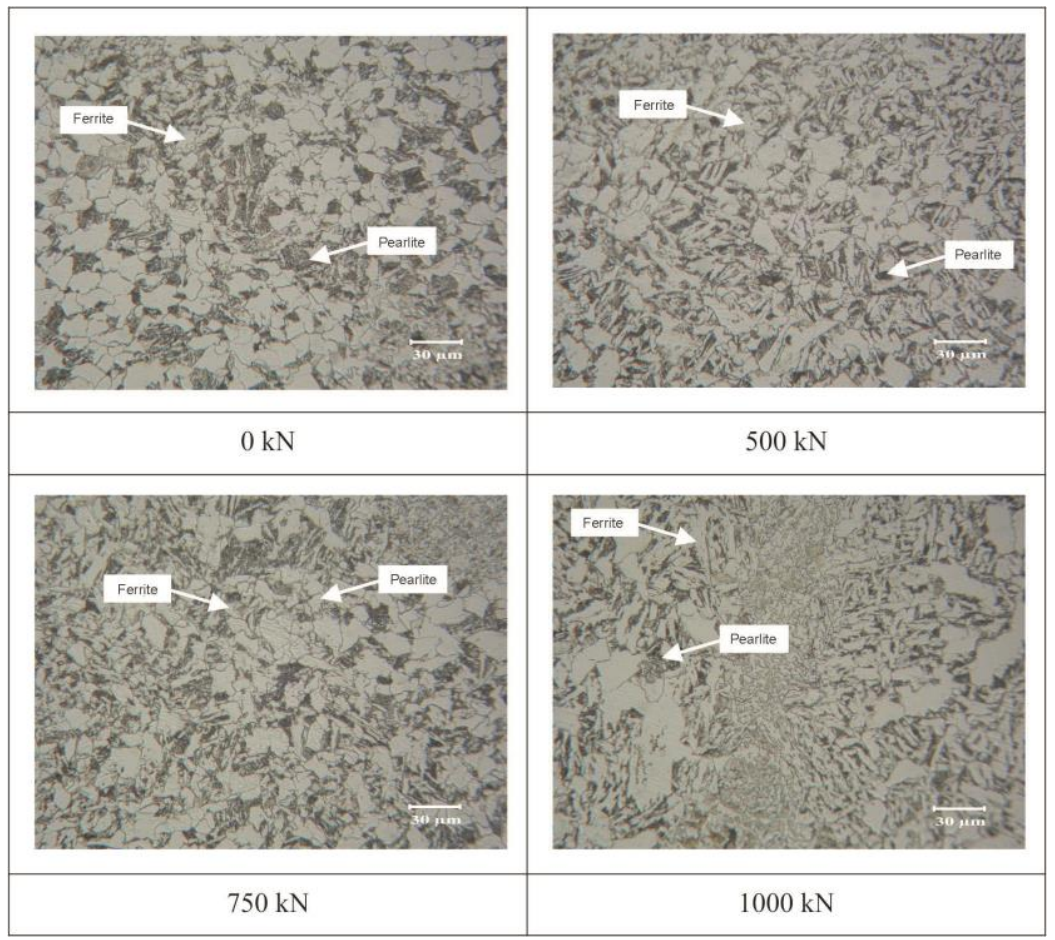

Fig. 6. The state of the microstructure under $1200^{\circ} \mathrm{C}$ different forging load conditions.

The observation of the microstructure shown in Figure 4 to Figure 6 below proved that during the hot forging process grain refining occurs by recrystallization mechanism seen from increasing number of grains compared with the variation without forging or as-cast steels. The analysis of magnification up to 500x and a visible phase formed from the hot forging is dominated by ferrite and perlite phases.

The Ni content having a weight percent of $1.7833 \%$, the ferrite-soluble nickel forms the FCC unit cell (an austenite stabilizer) and lowers the eutectoid temperature[8]. Ferritesoluble nickel increases toughness, lowering the Fracture Appearance Transition Temperature (FATT) 50\%, also triggering recrystallization resulting in smoothing of grains after heat deformation[1,9].

The hot forging process has an effect on the mechanical properties of laterite steel, the impact and hardness value[10] There was an increase of impact value on each temperature variation between the specimen without treatment and the specimen with forging force $1000 \mathrm{kN}$, at temperature of $800{ }^{\circ} \mathrm{C}$ reached $20 \%$, at temperature of $1000{ }^{\circ} \mathrm{C}$ equal to $16.36 \%$, and temperature of $1200{ }^{\circ} \mathrm{C}$ equal to $81.83 \%$. The increase of hardness properties at each temperature variation between specimen without treatment and specimen with forging force $1000 \mathrm{kN}$, at temperature of $800{ }^{\circ} \mathrm{C}$ equal to $3.37 \%$, temperature $1000{ }^{\circ} \mathrm{C}$ equal to $4.99 \%$, and temperature $1200{ }^{\circ} \mathrm{C}$ equal to $3.37 \%$. Impact and hardness values are increasing with increasing temperature and forging load. 
Authors would like to thank to all technician laterite Steel Group as well as funding from DIPA LIPI 2017.

\section{References}

1. A. He \& J. Zeng. Mater. Des. 115 (2017)

2. R. A. Higgins, Engineering Metallurgy Part 1 Applied Physical Metallurgy. 140-235 (1957)

3. S. Herbirowo, B. Adjiantoro, T. B. Romijarso \& A. Widya 20043 (2018)

4. M. Jahazi \& B. Eghbali 113 (2001)

5. S. Herbirowo \& B. Adjiantoro 266 (2017)

6. ASTM. Norma E23-07a - Standard Test Methods for Notched Bar Impact Testing of Metallic Materials. Am. Soc. Test. Mater. Handb. 14, 28 (2007).

7. M. Y. Hasbi, Saefudin \& T. B. Romijarso (2018)

8. S. Herbirowo \& T. B. Romijarso 1-2 (2017)

9. A.H. Ismoyo and B. Parikin 13-21 (2014)

10. S. Herbirowo, B. Adjiantoro \& T. B. Romijarso IOP Conf. Ser. Mater. Sci. Eng. 202, (2017) 